\title{
Healthcare waste management current status and potential challenges in Ethiopia: a systematic review
}

\author{
Teshiwal Deress Yazie ${ }^{*}$ (D), Mekonnen Girma Tebeje and Kasaw Adane Chufa
}

\begin{abstract}
Objective: During the healthcare delivery process, hazardous wastes can be generated from the health facilities. Improper healthcare waste management is responsible for the transmission of more than 30 dangerous bloodborne pathogens. The aim of this systematic review was to evaluate the healthcare waste management practice and potential challenges in Ethiopia.

Results: Electronic databases and direct Google search yielded 1742 articles from which 17 studies met the inclusion criteria. The proportion of hazardous waste generated in Ethiopian healthcare facilities was unacceptably high which ranged from 21 to $70 \%$. Most studies indicated the absence of proper waste segregation practice at the source of generation. Treatment of the healthcare waste using low combustion incinerator and/or open burning and open disposal of the incinerator ash were very common. Lack of awareness from the healthcare staff, appropriate waste management utilities and enforcement from the regulatory bodies were mainly identified as a common factor shared by most of the studies. The healthcare waste management practice in Ethiopian healthcare facilities was unsatisfactory. There should be close supervision of the waste disposal process by the regulatory bodies or other stakeholders.
\end{abstract}

Keywords: Healthcare waste, Waste management, Healthcare facility, Ethiopia

\section{Introduction}

During the healthcare delivery process, healthcare facilities (HCFs) can generate wastes and by-products [1]. Currently, there are several terms used to explain the waste generated from the HCFs such as; health facility waste, clinical waste, healthcare waste, medical waste, and biomedical waste. However, healthcare waste ( $\mathrm{HCW})$ is most frequently used by the articles published so far [2-24]. In this study, we used the term HCW to represent the total waste generated from the HCFs.

Healthcare waste is categorized as general and hazardous waste types [25-27]. General waste is the largest portion [26] which is originated from food preparation, administrative and housekeeping activities. Whereas, the

\footnotetext{
*Correspondence: teshiwalderess@gmail.com; teshiwal.deress@uog.edu.et Unit of Quality Assurance and Laboratory Management, School of Biomedical and Laboratory Sciences, College of Medicine and Health Sciences, University of Gondar, P.O. Box 196, Gondar, Ethiopia
}

hazardous waste is generated throughout the healthcare delivery process [19]. It includes laboratory wastes, pathological, body fluids, and sharp wastes [25, 26]. According to the guidelines, six consecutive healthcare waste management (HCWM) steps should be implemented by the HCFs [26, 28-31]. This successful management process includes segregation, collection, storage, transportation, treatment, and end up with final disposal $[17,26$, 32] (Fig. 1).

Proper disposal of the HCW has become a global concern due to its public health hazards [17, 25, 33]. According to the WHO estimation, $10-25 \%$ of the HCW is hazardous [26]. However, this proportion is varied from country to country which ranged between 16 and $75 \%$ $[6,8,12,14,21,23,34,35]$. Globally over two million healthcare workers are exposed to infections [26]. The $\mathrm{HCW}$ can transmit more than 30 dangerous bloodborne pathogens [36]. Poor HCWM is a problem particularly in most developing countries [5, 12, 37-40]. Several studies indicated that HCWM is still at infancy stage $[3,7,15$, 


\section{Segregation}

Separation of healthcare wastes according to their category and labelling waste containers. It is the most important step to reduce the risk and amount of hazardous waste. Adequate waste management receptacles and proper personal protective device supply is determinant factors.

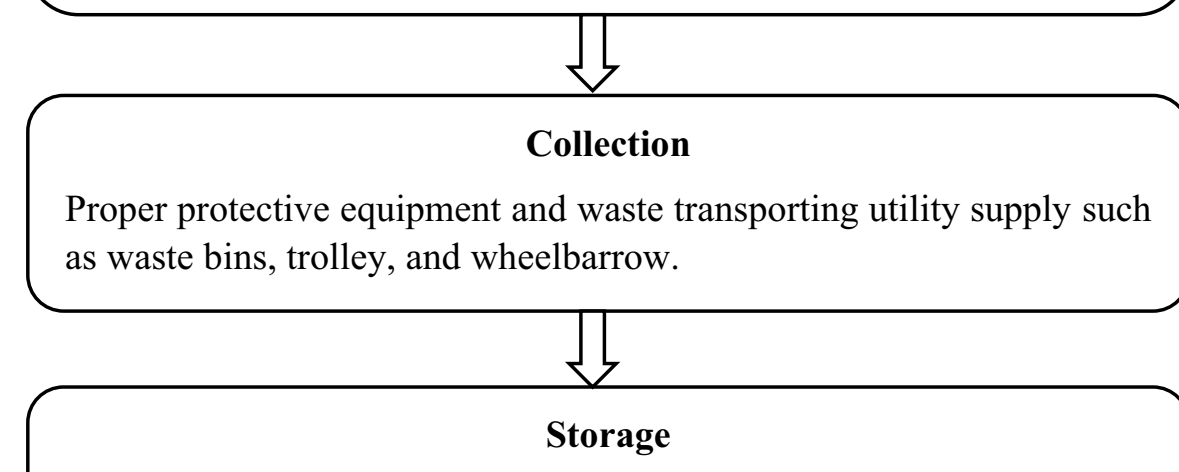

Secured and adequate temporary waste storage space allocation is vital. Waste storage time should be limited to $24-48$ hours.

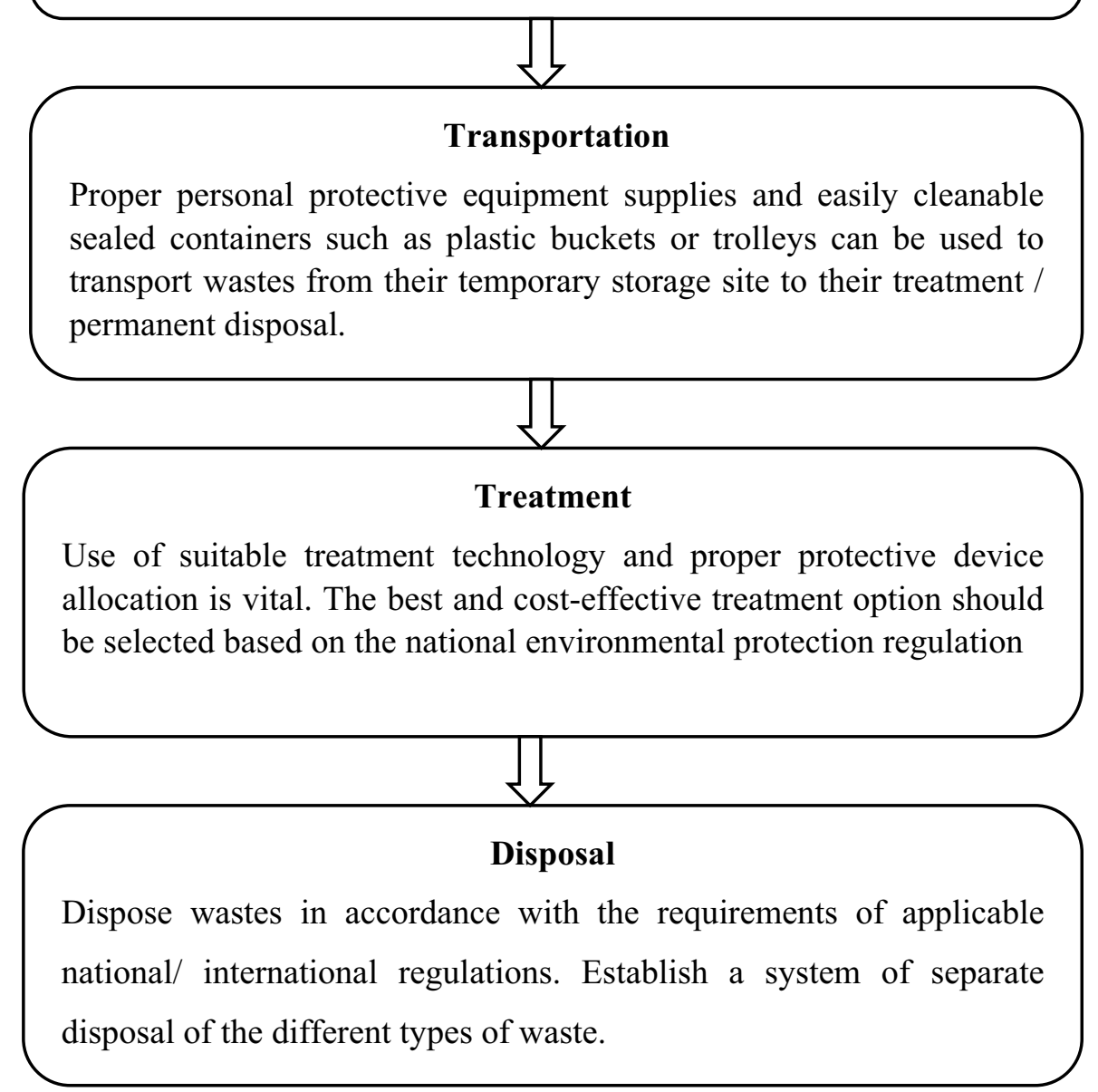

Fig. 1 Healthcare waste management process 
16] and particularly it is a neglected activity in Ethiopia [31]. Therefore, the aim of this systematic review was to evaluate the HCWM practice and potential challenges in Ethiopia.

\section{Main text \\ Methods}

Ethiopia is a highly populated country in Africa. During 2012 the Ethiopian population was predicted to be $84,320,987$ [41]. In parallel with the rapid population growth, the number of HCFs is increasing [13, 42]. The healthcare management is categorized as primary, secondary and tertiary levels. During 2011 there were 125 hospitals, 2999 health centers, 15,668 health posts and more than 4000 private clinics in the country [43]. The health post, health center, and primary hospitals serve a population of 3000-5000, 40000 and 60,000-10,000, respectively. General and specialized hospitals serve 1 to 1.5 and 3.5-5.0 million population, respectively [44].

A qualitative research design was employed to develop this systematic review. The study was conducted according to the PRISMA (Preferred Reporting Items for Systematic Reviews and Meta-Analyses) guidelines to ensure the inclusion of relevant information in the study [45]. Studies were eligible only if they were published in the English language in peer-reviewed journals, carried out in the Ethiopian context, and accessed in the full-text format.

Published articles were searched in PubMed and Google Scholar by two investigators (TD and MG). The search strategy was employed using a combination of keywords and Boolean functions; "healthcare waste" OR "medical waste" OR "clinical waste" OR "infectious waste" OR "hospital waste" OR "healthcare facility waste" OR hazardous waste" OR "biomedical waste" OR "medical waste" AND "Ethiopia". In addition, a direct Google search was also employed. Then, the searched articles from the two investigators were compiled together and screened for duplication. Finally, reference lists cited by each eligible study were assessed to identify additional articles. We used an endnote X9 version citation manager software to manage the citation.

Two authors (TD and KA) independently extracted data using the predefined data extraction sheet. Inconsistent data between the two data abstracters were resolved by discussion and involvement of a third coauthor (KA). Data were abstracted containing first author and year of publication, setting, key findings (availability of waste management utilities/devices, waste segregation practice, hazardous waste proportion, waste treatment, final disposal, potential challenges) and additional relevant findings were paraphrased.
Before starting data extraction, selection process of the relevant studies was explained under the characteristics of included studies using texts and graphical presentation. After data extraction, the findings were grouped together into three thematic areas 'waste generation, segregation and use of proper waste management utilities', 'waste treatment and disposal practices', and 'potential challenges. Finally, data were presented using texts.

To ensure reliability, articles were searched systematically using a combination of key terms and Boolean functions by two authors independently. The quality of the data was assured through extracting by two authors independently using the predefined data extraction checklist. Any inconsistent data from the two data extractors were resolved by discussion and involvement of a third coauthor (Kasaw). In addition, the review process was done using the PRISMA guidelines.

\section{Results}

\section{Characteristics of the included studies}

This systematic review was conducted on published studies which were conducted among the Ethiopian healthcare facilities. An online electronic search was done using Google Scholar and PubMed databases and we identified 834 articles. In addition, from reference lists of the included studies and direct Google search, we identified 908 articles. From a total of 1742 articles, 1619 data files were removed due to duplication. Further, 123 articles were refined by their title and abstract and 104 studies were excluded due to short communication, lack of relevant data with respect to this systematic review, unpublished student thesis, studies conducted elsewhere in another country, a review article on the legal framework, and letters to editors. Nineteen full-text articles were reviewed and two of them were excluded due to lack of relevant information for this systematic review as one study was conducted on developing new models for HCWM and the other was conducted on the prevalence of injuries associated with the mismanagement of HCWs among the waste collectors. Finally, we included 17 fulltext articles (Fig. 2).

\section{Waste generation, segregation and use of utilities}

Most studies were obtained from the central and northwest regions of Ethiopia. Studies indicated no waste segregation practice $[2,13,14,17,44]$. In some cases; however, there was very limited segregation $[5,6,8,18$, $20,21,46]$. Due to this reason, the proportion of the hazardous waste generation rate becomes unacceptably high which range from 21 to $75 \%$ [2, 6, 9, 12, 14, 17, 21, 23]. Privately owned HCFs generated a higher proportion of hazardous wastes than government-run facilities [23]. There was no use of proper color-coded bins for waste 


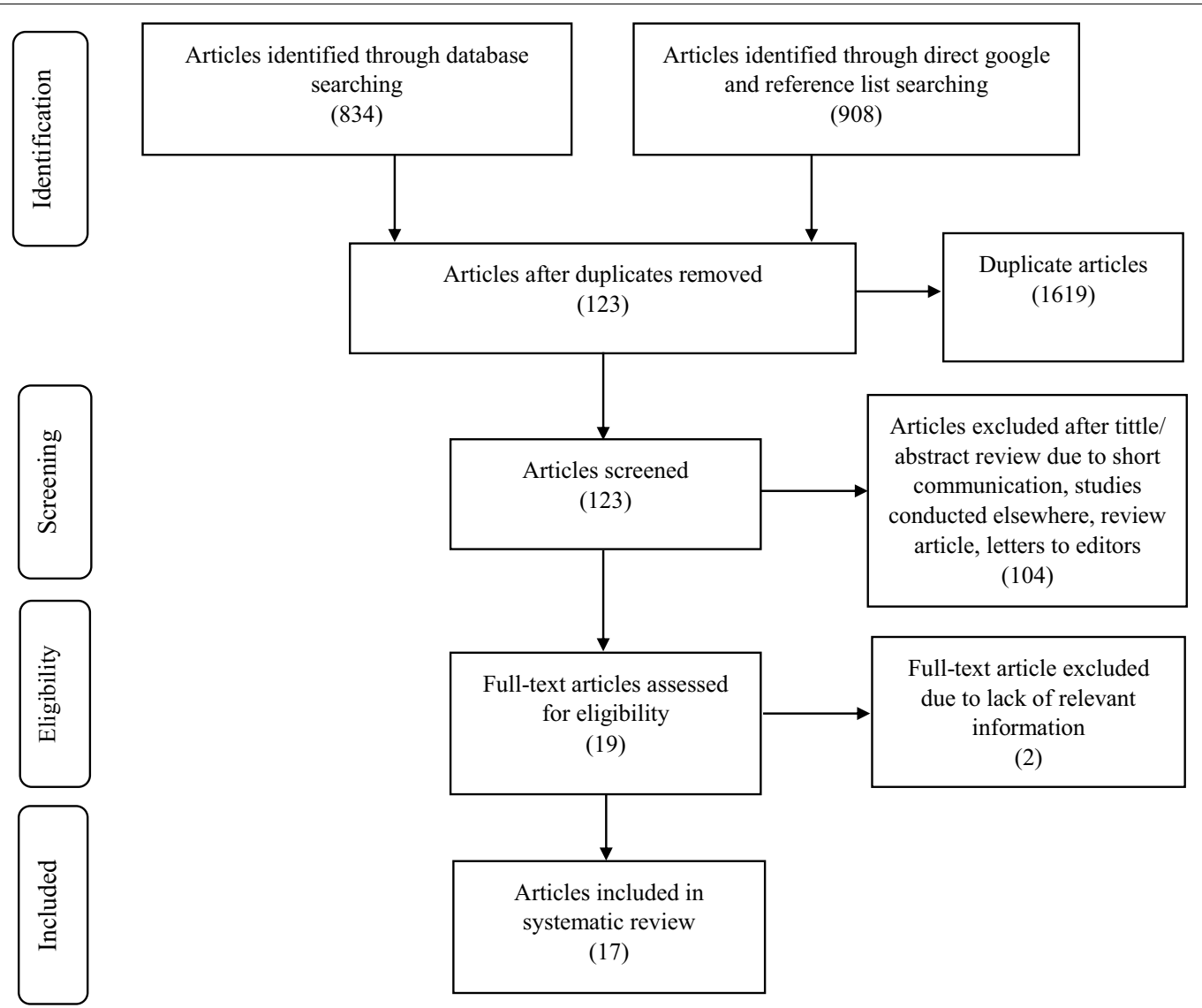

Fig. 2 Flowchart to describe the selection of articles for the systematic review

segregation [5, 9]. General and infectious wastes were mixed together [9]. Plastic buckets were used to store the HCW temporarily $[17,27]$. Disinfection of waste storage and/or transporting utilities was uncommon $[6,17]$.

\section{Waste treatment and disposal practices}

Low combustion incinerator was used to treat all the HCW types $[2,8,9,12,14,21,46]$. In other cases, studies indicated the use of incineration and open burning methods to treat hazardous and general wastes, respectively $[5,6,8,14,17,20,27]$. With respect to disposal of the treated waste by-products, some studies used burial pit $[2,6]$ while other studies disposed of in an unsanitary way simply by open dumping $[8,12,27]$.

\section{Potential challenges}

In the Ethiopian context, there was no separate regulation specific for the HCFs to enforce them for the proper management of the hazardous waste. Though currently they are not updated and lacked proper compliance on their implementation, there are three HCWM guidelines prepared by the Federal Ministry of Health (FMoH),
Food, Medicine and Healthcare Administration and Control Authority (FMHACA), and Federal Environmental Protection Authority (FEPA) independently [29, 30, 46]. In addition, studies indicated lack of training, awareness, staff resistance, managerial poor commitment, lack of adequate resources, negligence, and unfavorable attitude of the healthcare staff were the main identified challenges $[8,10,12-14,46,47]$. Most studies measured the aforementioned potential factors either quantitatively or qualitatively that could affect HCFs to implement the proper waste management practices.

\section{Discussion}

Currently, HCWM is a public health and environmental concern worldwide particularly in the developing countries [4, 48]. Hazardous waste mismanagement affects all individuals particularly healthcare providers. The general and hazardous waste types should be properly segregated at their source of generation [25, 49-51]. However, in this systematic review, studies mentioned the absence of waste segregation practices $[2,5,12,14,17,20,21,32$, 44]. Probably this could be due to lack of the appropriate 
waste segregation utilities, lack of awareness or lack of enforcing laws and/or regulations. It is also a continentwide problem by which a systematic review in the African region indicated that $47 \%$ of the studies mentioned the absence of waste segregation [52]. The proportion of hazardous $\mathrm{HCW}$ is varied in Ethiopia which ranged from 21 to $70 \%[14,44]$. This proportion is higher than the hazardous waste threshold (10-25\%) predicted by the WHO [26]. In one study, even the amount of hazardous waste was higher than the general waste [14]. This could be due to the fact that during the segregation process even a very small amount of hazardous waste is added to the general waste category, then the entire mass of the general waste can be unnecessarily polluted by the hazardous waste.

The segregated $\mathrm{HCW}$ types are required to be collected separately using waste collecting utilities designed for each type of HCW [26, 31]; however, in this systematic review, studies indicated the aggregate collection of the different HCW types using a single container $[9,17,21]$. This could be due to the lack of awareness of the health hazards associated with the aggregate collection of all the $\mathrm{HCW}$ types by the waste collectors because in Ethiopian context waste collectors are mostly recruited from the low educational level and they might not provide adequate training as the healthcare professionals.

According to WHO guidelines, all hazardous $\mathrm{HCW}$ types generated from the HCFs should be stored in utility rooms prepared for cleaning equipment, dirty linen and waste storage [26]. If these facilities are not available, the HCW can be stored in other secured locations [31, 53]. However, studies indicated hazardous waste storage practices using the primary waste segregation containers stationed around the corridors $[27,44]$. This unacceptable waste storage practice could probably due to the lack of sufficient and isolated waste storage spaces away from direct public access.

Incineration is the most widely used waste treatment method to treat hazardous $\mathrm{HCW}$ before the final disposal particularly in most developing countries. In Ethiopia, incineration and open burning are common treatment methods to treat hazardous and general waste types, respectively. However, incinerators are often operated under sub-optimal conditions mostly with untrained personnel [4]. Thus, due to inadequate incineration harmful substances can be released into the environment [27]. Regarding disposal of the HCW, incinerator ash is commonly disposed of in burial pit or open dumping. Most studies showed HCWM noncompliance with the requirements of the national and international guidelines $[2,5,6$, $8,9,12,14,18,21,27,44]$. This could be due to lack of the appropriate quantity and/or type of waste management utility supply, adequate financial allocation, specific laws, and regulations.
Healthcare waste management is a complex and challenging process and in this systematic review lack of training [2, 5], accessible guideline [2, 6, 12, 21, 46], regular supervision, appropriate utility supply, management support, and specific rules/regulations are identified as a major challenge for having effective waste management system [5, 13, 17, 23, 24, 27, 44, 46] that needs establishment of an immediate strategy to reduce the potential problems associated with the mismanagement of the hazardous wastes emanated from the healthcare establishments.

In conclusion, the $\mathrm{HCW}$ generation rate was high but its management very poor. Lack of accessible guideline, waste management utility, adequate training, financial constraint, and poor managerial supports were identified as the main challenges. There should be sufficient resource allocation, periodic training, and strict supervision by the stakeholders.

\section{Limitations}

In this systematic review, liquid waste management was not considered. In addition, recycling practices of the reusable materials from the HCWs were not considered.

\section{Abbreviations}

HCW: healthcare waste; HCFs: healthcare facilities; HCWM: healthcare waste management.

\section{Acknowledgements}

Not applicable.

\section{Authors' contributions}

TD and MG participated during collecting relevant articles from the databases. After articles have been collected, KA and TD extracted data and prepared the draft manuscript. Then, MG revised the manuscript. Finally, TD and MG finalized the manuscript and TD communicated with the journal. All authors read and approved the final manuscript.

\section{Funding}

Not applicable.

Availability of data and materials

Not applicable.

Ethics approval and consent to participate

Not applicable.

\section{Consent for publication}

Not applicable.

\section{Competing interests}

The authors declare that they have no competing interests.

Received: 3 January 2019 Accepted: 18 May 2019

Published online: 23 May 2019

References

1. Pinto VN, Joshi SM, Velankar DH, Mankar MJ, Bakshi H, Nalgundwar A. A comparative study of knowledge and attitudes regarding biomedical 
waste (BMW) management with a preliminary intervention in an academic hospital. Int J Med Public Health. 2014;4:91-5.

2. Abebe S, Raju R, Berhanu G. Health care solid waste generation and its management in Hawassa Referral Hospital of Hawassa University, Southern, Ethiopia. Int J Innov Res Dev. 2017;6:126-32.

3. Alagoz AZ, Kocasoy G. Determination of the best appropriate management methods for the health-care wastes in Istanbul. Waste Manage. 2008;28:1227-35.

4. Asante OB, Yanful E, Yaokumah EB. Healthcare waste management; its impact: a case study of the greater Accra Region, Ghana. Int J Sci Technol Res. 2014;3:106-12.

5. Azage M. Healthcare waste management practices among healthcare workers in healthcare facilities of Gondar town, Northwest Ethiopia. Health Sci J. 2013;7:315-26.

6. Azage M, Kumie A. Healthcare waste generation and its management system: the case of health centers in West Gojjam Zone, Amhara Region, Ethiopia. Ethiop J Health Dev. 2010;24:119-26.

7. Bendjoudi Z, Taleb F, Abdelmalek F, Addou A. Healthcare waste management in Algeria and Mostaganem department. Waste Manag. 2009:29:1383-7.

8. Debalkie D, Kumie A. Healthcare waste management: the current issue in Menellik II Referral Hospital, Ethiopia. Curr World Environ. 2017;12:42-52.

9. Debere MK, Gelaye KA, Alamdo AG, Trifa ZM. Assessment of the health care waste generation rates and its management system in hospitals of Addis Ababa, Ethiopia, 2011. BMC Public Health. 2013;13:28.

10. Doylo T, Alemayehu T, Baraki N. Knowledge and practice of health workers about healthcare waste management in public health facilities in Eastern Ethiopia. J Community Health. 2018:43:1-8.

11. EsubalewT. Assessment of health care waste generation rate and evaluation of health care waste management in Debre Birhan zonal hospital. M.Sc. Thesis, School of public health, Addis Ababa University, 12, 2007.

12. Haylamicheal ID, Dalvie MA, Yirsaw BD, Zegeye HA. Assessing the management of healthcare waste in Hawassa city, Ethiopia. Waste Manage Res. 2011;29:854-62.

13. Haylamicheal ID, Desalegne SA. A review of legal framework applicable for the management of healthcare waste and current management practices in Ethiopia. Waste Manage Res. 2012;30:607-18.

14. Hayleeyesus SF, Cherinete W. Healthcare waste generation and management in public healthcare facilities in Adama, Ethiopia. J Health Pollut. 2016;6:64-73.

15. Manga VE, Forton OT, Mofor LA, Woodard R. Healthcare waste management in Cameroon: a case study from the south-western region. Resour Conserv Recycl. 2011;57:108-16.

16. Mbongwe B, Mmereki BT, Magashula A. Healthcare waste management: current practices in selected healthcare facilities, Botswana. Waste Manage. 2008;28:226-33.

17. Meleko A, Adane A. Assessment of health care waste generation rate and evaluation of its management system in Mizan Tepi University Teaching Hospital (MTUTH), Bench Maji Zone, South West Ethiopia. Ann Rev Res. 2018;1:1-9.

18. Mesfin A, Worku W, Gizaw Z. Assessment of health care waste segregation practice and associated factors of health care workers in Gondar University Hospital, North West Ethiopia, 2013. Univ J Public Health. 2014;2:201-7.

19. Patil $A D$, Shekdar AV. Health-care waste management in India. J Environ Manage. 2001;63:211-20.

20. Sahiledengle B, Gebresilassie A, Hiko K, Getahun T. Healthcare waste segregation, treatment and disposal practice in governmental healthcare facilities in Addis Ababa, Ethiopia. Ethiop J Environ Stud Manage. 2018;11:73-85

21. Tadesse ML, Kumie A. Healthcare waste generation and management practice in government health centers of Addis Ababa, Ethiopia. BMC Public Health. 2014;14:1221.

22. Tesfahun E, Kumie A, Beyene A. Developing models for the prediction of hospital healthcare waste generation rate. Waste Manage Res. 2016:34:75-80

23. Tesfahun E, Kumie A, Legesse W, Kloos H, Beyene A. Assessment of composition and generation rate of healthcare wastes in selected public and private hospitals of Ethiopia. Waste Manage Res. 2014;32:215-20.

24. Yenesew MA, Moges HG, Woldeyohannes SM. A cross sectional study on factors associated with risk perception of healthcare workers toward healthcare waste management in healthcare facilities of Gondar Town, Northwest Ethiopia. Int J Infect Control. 2012;8:1-9.

25. Olufunsho A, Aishat AA, Azuka CO. Assessment of medical waste management in seven hospitals in Lagos, Nigeria. BMC Public Health. 2016;16:269.

26. Chartier Y, Emmanuel J, Pieper U, Prüss A, Rushbrook P, Stringer R, et al. Safe management of wastes from health-care activities. Geneva, Switzerland: World Health Organization; 2014

27. Derso S, Taye G, Getachew T, Defar A, Teklie H, Amenu K. Biomedical waste disposal systems of health facilities in Ethiopia. Environ Health Eng Manage J. 2018;5:1-9.

28. Bokhoree C, Beeharry Y, Makoondlall CT, Doobah T, Soomary N. Assessment of environmental and health risks associated with the management of medical waste in mauritius. APCBEE Procedia. 2014;9:36-41.

29. The Federal Environmental Protection Authority (FEPA). Technical guidelines on the environmentally sound management of biomedical and healthcare wastes. Addis Ababa: The Federal Environmental Protection Authority (FEPA); 2004.

30. Food, Medicine and Healthcare Administration and Control Authority (FMHACA). Healthcare waste management directive. Addis Ababa: Food, Medicine and Healthcare Administration and Control Authority (FMHACA); 2005.

31. Federal Ministry of Health (FMoH). Healthcare waste management national guidelines, hygiene and environmental health development. Addis Ababa: Federal Ministry of Health (FMoH); 2008.

32. Manyele SV, Lyasenga TJ. Factors affecting medical waste management in low level health facilities in Tanzania. Afr J Environ Sci Technol. 2010;4:304-18.

33. Chakraborty S, Veeregowda B, Gowda L, Sannegowda SN, Tiwari R, Dhama K, et al. Biomedical waste management. Adv Anim Vet Sci. 2014:2:67-72.

34. Bassey BE, Benka-Coker MO, Aluyi HS. Characterization and management of solid medical wastes in the federal capital territory, Abuja Nigeria. Afr Health Sci. 2006;6:59-63.

35. Sarkar SK, Haque MA, Khan TA. Hospital waste management in Sylhet city. ARPN J Eng Appl Sci. 2006;1:32-40.

36. Sawalem M, Selic E. Hospital waste management in Libya: a case study. Waste Manage. 2009:29:1370-5.

37. Hossain MS, Santhanam A, Norulaini NN, Omar AM. Clinical solid waste management practices and its impact on human health and environment—a review. Waste Manage. 2011;31:754-66.

38. De Titto E, Savino AA, Townend WK. Healthcare waste management: the current issues in developing countries. Waste Manag Res. 2012;30:559-61.

39. Townend B, Vallini G. Healthcare waste management-the global paradox. Waste Manage Res. 2008;26:215-6.

40. Diaz LF, Fisher S. Management of healthcare wastes. Waste Manage. 2005;25:567-74.

41. Federeal Democratic Republic of Ethiopia Ministry of Health, Health and Health Related Indicators 2004 E.C 2011/12.

42. Eshetie S, Gizachew M, Dagnew M, Kumer G, Woldie H, Ambaw F, et al. Multidrug resistant tuberculosis in Ethiopian settings and its association with previous history of anti-tuberculosis treatment: a systematic review and meta-analysis. BMC Infect Dis. 2017;17:219.

43. Federal Democratic Republic of Ethiopia. Health and health related indicators. Ethiopia: Federal Democratic Republic of Ethiopia; 2011.

44. Abebe A. Study of hazardous biomedical waste management practices and development of hazardous biomedical waste management guidelines in Addis Ababa. Int J Sci Eng Sci. 2017;1:19-32.

45. Moher D, Liberati A, Tetzlaff J, Altman DG, Group P. Preferred reporting items for systematic reviews and meta-analyses: the PRISMA statement. PLoS Med. 2009;6:e1000097.

46. Demissie F. Hazardous waste management by healthcare institutions, Addis Ababa: implementation of laws and regulation. Ethiop J Environ Stud Manage. 2014;7:134-41.

47. Deress T, Hassen F, Adane K, Tsegaye A. Assessment of knowledge, attitude, and practice about biomedical waste management and associated factors among the healthcare professionals at Debre Markos Town Healthcare Facilities, Northwest Ethiopia. J Environ Public Health. 2018;2018:1-10. 
48. Sabageh A, Adeomi A, Adediran O, Abodunrin O, Oladimeji O, Eunice F. Perception and practices of healthcare workers in Southwestern Nigeria towards healthcare waste management. Br J Med Health Res. 2015;2:19-26.

49. Longe E, Williams A. A preliminary study of medical waste management in Lagos metropolis, Nigeria. J Environ Health Sci Eng. 2006;3:133-9.

50. Ngwuluka N, Ochekpe N, Odumosu P, John SA. Waste management in healthcare establishments within Jos Metropolis, Nigeria. Afr J Environ Sci Technol. 2009:3:459-65.

51. Ola-Adisa EO, Mangden YE, Sati YC, Adisa JO. Knowledge, Attitudes/ beliefs and practices in medical waste management-an appraisal of Jos North LGA, Plateau State, Nigeria. Int J. 2015;2:43-56.
52. Emilia A, Julius N, Gabriel G. Solid medical waste management in Africa. Afr J Environ Sci Technol. 2015;9:244-54.

53. Ruth S. Medical waste and human rights. Health care without harm; Submission to the UN human rights council special rapporteur. 2011.

\section{Publisher's Note}

Springer Nature remains neutral with regard to jurisdictional claims in published maps and institutional affiliations.
Ready to submit your research? Choose BMC and benefit from:

- fast, convenient online submission

- thorough peer review by experienced researchers in your field

- rapid publication on acceptance

- support for research data, including large and complex data types

- gold Open Access which fosters wider collaboration and increased citations

- maximum visibility for your research: over $100 \mathrm{M}$ website views per year

At BMC, research is always in progress.

Learn more biomedcentral.com/submissions 